mum temperature at which life is possible may be nonenzymatic hydrolysis of ATP.

This work was supported by a NASA grant.

H. R. HULETT

Department of Genetics,

Stanford University School of Medicine,

Stanford, California 94305.

Received December 15, 1969.

${ }^{1}$ Titas, M., and Lowenstein, J. M., Biochemistry, 2, 350 (1963).

2 Miller, D. I., and Westheimer, F. H., J. Amer. Chem. Soc., 88, 1507 (1966).

a Cloud, jun., P. E., Science, 160, 729 (1968).

Lowry, O. H., and Lopez, J. A., J. Biol. Chem., 162, 421 (1946).

b Brock, T. D., Science, 164, 1411 (1969).

\section{Possible Basis for the Cariostatic Effect of Inorganic Phosphates}

INORGANIC phosphates are effective in reducing dental caries when added as supplements to cariogenic diets fed to rodents ${ }^{1}$, and when added to chewing gum ${ }^{2}$ and to breakfast cereal eaten by children ${ }^{3}$. Because the caries process may be influenced by pellicle proteins ${ }^{4}$, and salivary proteins adsorbed to human enamel are differentially eluted by water and orthophosphate solutions ${ }^{5}$, we reasoned that the cariostatic effect of phosphate might involve one or both of the following processes: $(a)$ differential elution of proteins adsorbed on enamel; $(b)$ modification of the enamel surface resulting in an alteration of the acquired protein layer. To test this hypothesis in a model system we have studied the effects of phosphates on enzymes adsorbed to human enamel.

Samples $(50 \mathrm{mg})$ of purified human enamel powder ${ }^{6}$ were equilibrated at room temperature with $1 \mathrm{ml}$. of a $0.1 \mathrm{mg} / \mathrm{ml}$. solution of purified amylase (from Aspergillus oryzeae). The supernatant was decanted and the enamel samples were washed with $1 \mathrm{ml}$. of water, or with $1 \mathrm{ml}$. of saturated CaHPO, solution $(1.8 \mathrm{mM})^{7}$, or with $1 \mathrm{ml}$. of $1.8 \mathrm{mM}$ solutions of either $\mathrm{NaH}_{2} \mathrm{PO}_{4}$ or $\mathrm{Na}_{3}\left(\mathrm{PO}_{3}\right)_{3}$. All solutions were at $p \mathrm{H} \mathrm{6 \cdot 0.} \mathrm{Each} \mathrm{of} \mathrm{four} \mathrm{successive} 1 \mathrm{ml}$. washings was assayed for desorbed amylase activity. (We have found that the presence of these phosphates at a concentration of $1.8 \mathrm{mM}$ does not interfere with the normal exprcssion of amylase activity.) The results are shown in Table 1.

Table 1. DESORPTION OF AMYLAST FROM HUMAN ENAMEI

\begin{tabular}{|c|c|c|c|c|}
\hline \multirow{2}{*}{ Wash number } & \multicolumn{4}{|c|}{$\begin{array}{l}\text { Units* of amylase desorbed from } 50 \mathrm{mg} \text { of } \\
\text { enamel powder by } 1 \mathrm{ml} \text {. washes of: }\end{array}$} \\
\hline & $\mathrm{H}_{2} \mathrm{O}$ & CaHPO & $\mathrm{NaH}_{2} \mathrm{PO}_{4}$ & $\mathrm{Na}_{3}\left(\mathrm{PO}_{3}\right)_{3}$ \\
\hline 1 & $0 \cdot 24$ & 0.60 & $1 \cdot 53$ & $2 \cdot 05$ \\
\hline 2 & 0.19 & $0 \cdot 30$ & 0.64 & 0.73 \\
\hline 3 & 0.00 & $0 \cdot 13$ & 0.18 & 0.17 \\
\hline$\stackrel{4}{4}$ & 0.00 & 0.08 & 0.10 & \\
\hline four washes & $0 \cdot 43$ & $1 \cdot 11$ & $2 \cdot 45$ & $2 \cdot 95$ \\
\hline
\end{tabular}

* 1 unit of amylase catalyses the release of $1 \mathrm{mM}$ of maltose per min from a 1 per cent soluble starch solution at $25^{\circ} \mathrm{C}$. The phosphate concentrations were $1.8 \mathrm{mM}$.

Water desorbed very little amylase. The activity in the first eluant portion is probably the result of amylase remaining in the interstitial fluid after removal of the supernatant. Desorption effectiveness of the solutions was in the order $\mathrm{Na}_{3}\left(\mathrm{PO}_{3}\right)_{3}>\mathrm{NaH}_{2} \mathrm{PO}_{4}>\mathrm{CaHPO}_{4}>\mathrm{H}_{2} \mathrm{O}$. Similar desorption studies were made with purified hen's egg white lysozyme. Lysozyme was not desorbed by any of the $1.8 \mathrm{mM}$ phosphate solutions, but was desorbed by sodium orthophosphate at a concentration of $40 \mathrm{mM}$ and by I per cent (by weight) sodium trimetaphosphate (TMP) solutions.

We investigated the possibility of surface modification by pretreating enamel with $1.8 \mathrm{mM}$ phosphate solutions before adsorption of the enzymes. Only TMP altered the adsorption propertios of the cnamel. Amylase adsorbed to TMP treated enamel was easily removed by water, and TMP treated enamel adsorbed 2 to 3 times as much lysozyme activity as untreated enamel. The alteration of the enamel surface by trimetaphosphate was not a simple detergent effect. Pretreatment of enamel with either a $0 \cdot 1$ or 1.0 per cent (by weight) solution of 'Triton $X-100$ ' (isooctylphenoxypolyethoxyethanol, a biodegradable nonionic, surface active agent) had no effect on subsequent enzyme adsorption by the enamel. In the mouth, salivary proteins adsorbed on the tooth surface ${ }^{9}$ might protect enamel from alteration by phosphate. We found, however, that solutions of TMP produced the same effects on enamel powder which had first been equilibrated with centrifuged whole saliva.

While our results do not exclude the possibility of other mechanisms of action, they support the hypothesis that the basis of the cariostatic effect of inorganic phosphates is a modification of the composition of the protein layer adsorbed on enamel and, in the case of TMP, an alteration in the surface of the enamel with resulting change in the affinity of various salivary proteins for the enamel surface.

We thank Dr Charles Bugg of the Institute of Dental Research for initially drawing our attention to this problem and for discussion.

K. M. Pruitt

A. D. JAMIESON

R. C. CALDWELI

Institute of Dental Research and

Laboratory of Molecular Biology,

University of Alabama,

Birmingham, Alabama.

Received October 20; revised December 9, 1969.

1 Nizel, A. F., and Harris, R. S., J. Dent. Res., 43, 1123 (1964).

2 Finn, S. B., and Jamison, H., J. Amer. Dent. Assoc., 74, 988 (1967).

${ }^{s}$ Stookey, G. K., Carroll, P. A., and Muhler, J. C., J. Amer. Dent. Assoc., '74, $752(1967)$.

Dawes, C., Jenkins, G. N., and Tonge, C. H., Brit. Dent. J., 115, 65 (1963).

5 Pruitt, K. M., and Caldwell, R. C., J. Dent. Res., IADR Abst., 174 (1968).

'Manly, R. S., and Hodge, H. C., J. Dent. Res., 18, 133 (1939).

"Handbook of Physics and Chemistry (edit. by Weast, R. C.), forty-ninth ed., B-187 (Chemical Rubber Co., Cleveland, 1968).

${ }^{8}$ Jamieson, A. D., Pruitt, K. M., and Caldwell, R. C., J. Dent. Res., 48, 483 (1969).

- Pruitt, K. M., Caldwell, R. C., Jamieson, A. D., and Taylor, R. E., J. Dent. Res., 48, Supplement to No. 5, 818 (1969).

\section{Production of "Sulphation Factor" by the Perfused Liver}

LONGITUDINAI growth of the mammalian skeleton oceurs at the epiphyseal plate where chondrocytes proliferate and synthesize a matrix composed of collagen and a group of sulphated polysaccharides. In spite of the well known requirement for growth hormone to sustain longitudinal skeletal growth, a direct effect of the hormone on cartilage metabolism has not been demonstrated. The incorporation of sulphate into the organic matrix of cartilage is stimu. lated by a component of normal serum which is not growth hormone. This factor is absent in the serum of hypophysectomized animals, including man, but is restored by the administration of growth hormone. In addition to the stimulation of sulphate incorporation into polysaccharide, collagen synthesis and cell replication are also enhanced. Because the original assay for this component involved measurement of the incorporation of radioactive sulphate into the cartilage of hypophysectomized rats, the term "sulphation factor" was proposed by Salmon and Daughaday ${ }^{1}$. The source of this factor as well as its composition have been unknown.

The fact that liver is one of the few tissues which has been shown to respond to growth hormone in vitro ${ }^{2}$ makes it a likely source of sulphation factor. The work reported here demonstrates that the liver is capable of producing sulphation factor during perfusion with bovine growth hormone (BGH). 